ISSN 2616-7328 (Online), ISSN 2409-904X (Print)

Kitaêznavčì doslìdžennâ, 2018, No. 2, pp. 15-34

doi: https://doi.org/10.15407/chinesest2018.02.015

UDC 94(510)“19”:14

\title{
THE HISTORICAL STAGES OF THE DEVELOPMENT OF PHENOMENOLOGY IN CHINA
}

\section{Kiktenko}

DSc (Philosophy), Senior Fellow

A. Yu. Krymskyi Institute of Oriental Studies, NAS of Ukraine

4, Hrushevskoho Str., Kyiv, 01001, Ukraine

kiktenko@gmail.com

The article discusses the history of the development of the phenomenological movement in China from the 1920s to the present day. It is noted that the ideas of phenomenology gradually penetrated into China during the $1920 \mathrm{~s}-1960 \mathrm{~s}$, but by the end of the 1970s, translations and studies of the classics of Western phenomenology in China were not numerous and unsystematic. From the late 1970s to the mid - 1980s, it was occurred the full dissemination of phenomenology in China. Then, from the late 1980s to the mid - 1990s, it was started the process of translation into Chinese of the fundamental phenomenological works of E. Husserl, M. Heidegger, J.-P. Sartre, M. Scheler. Later, from the mid - 1990s to the present, this translation work reached a systemic level, which positively influenced on the development of phenomenology in China. At present, phenomenology in China is mainly at the stage of perception of this direction of Western thought and the formation of own phenomenological researches. Those researches can be distinguished into three main trends: 1) the relevance of phenomenology for Confucianism and Buddhism, 2) phenomenology in historical context, 3) dialogue between phenomenology and analytical philosophy. All this demonstrates the successful integration of Chinese philosophers into world science, they also form their own view of understanding the structure of human consciousness.

Keywords: phenomenology, consciousness, being, time, intentionality, Confucianism, Daoism, Buddhism, China and the West

\section{ІСТОРИЧНІ ЕТАПИ РОЗВИТКУ ФЕНОМЕНОЛОГІЇ В КИТАЇ}

\section{B. О. Кіктенко}

Наприкінці XIX століття китайські інтелектуали почали знайомитися із західною філософією, і поступово вже у ХХ столітті ідеї гегельянства, неокантіанства, ніцшеанства, марксизму, реалізму, прагматизму, логічного позитивізму, соціального дарвінізму та інших напрямів проникли в Піднебесну. Однак феноменологічний рух, важливий напрям “континентальної філософiї”, поширився в Китаї порівняно недавно. Окремі аспекти історії розвитку феноменологічного напряму в Китаї були досліджені в роботах Ні Лянкана та Iсо Керна “Феноменологічні дослідження в Китаї” [Ni Liangkang 1997], Джей Гулдінга "Сюн Вей: китайська філософія і феноменологія герменевтики" [Goulding 2004], Цзінь Сіпіна “Шень Юдін: перший феноменолог Китаю” [Jin

(C) 2018 V. Kiktenko; Published by the A. Yu. Krymskyi Institute of Oriental Studies, NAS of Ukraine and the Ukrainian Association of Sinologists on behalf of The Chinese Studies. This is an Open Access article distributed under the terms of the Creative Commons Attribution License (https://creativecommons.org/licenses/by-nc-nd/4.0/). 
Xiping 2007], Ісо Керна “Китай” в “Енциклопедії феноменології” [Kern 2007], Чжан Сянлуна “Феноменологічна думка в Китаї” [张祥龙 2011], Джулії Янсен та Цай Веньцін "Гуссерліанська феноменологія: сучасні китайські перспективи" [Jansena 2018]. У нашій роботі зроблено огляд історії та сучасного стану феноменологічного руху в Китаї.

\section{1. Феноменологія в Китаї: перше знайомство (1920-1960-ті роки)}

У Східній Азії ідеї феноменології спочатку проникли до Японії, потім Кореї і тільки після цього в Китай. “Філософський словник” (“哲学辞典”) 1926 року за редакцією Фань Бінціна (樊炳清, 1877-1929) містить статтю, у якій роз'яснюється предмет феноменології (现象学, xiànxiàngxué), але в розумінні I. Канта і Г. В. Ф. Гегеля, а не Е. Гуссерля [樊 炳 清 1926]. Проте це найперша згадка феноменології в Китаї. У 1928 році був опублікований переклад китайською мовою статті “Сучасна філософія" японського філософаекзистенціаліста, засновника кіотоської школи Нісіда Кітаро (にしだきたろう, 1870-1945). Трохи пізніше, у 1929 році, з'явилася стаття Ян Женьгена (楊人 梗, 1903-1973) “Вступ до феноменології” (“現象學概論”), у якій вперше китайському читачеві була представлена філософська система Е. Гуссерля [楊 人梗 1929]. I хоча всі ці публікації не привернули до себе великої уваги китайських філософів того часу, проте вони ознаменували собою початок проникнення в Китай феноменологічного руху, який, однак, до 1930-х років не вивчався і не мав своїх послідовників серед китайських вчених. При цьому ім'я Е. Гуссерля в деяких роботах зрідка згадувалося. Зміни відбулися завдяки трьом китайським студентам (Шень Юдіну, Вей Сюну і Сяо Шиі), які в 1930-ті роки здобули філософську освіту в західних університетах, а по поверненні на батьківщину зробили великий внесок у просування цього напрямку західної думки в Китаї.

Шень Юдін (沈有鼎, 1908-1989) ${ }^{1}$ у період з 1931-го по 1934 рік навчався в Гейдельберзькому університеті і Фрайбурзькому університеті під керівництвом М. Хайдеггера, був особисто знайомий з Е. Гуссерлем [沈有鼎 1992, 539]. В історії китайської філософії XX століття Шень Юдіна традиційно відносять до представників аналітичної філософії, а більша частина його робіт присвячена математичній логіці та інтерпретації традиційних китайських логічних ідей ${ }^{2}$. Справді, Шень Юдін не переймався феноменологічними питаннями про внутрішню структуру свідомості, а коли використовував у своїх дослідженнях гуссерліанську модель епістемології, то рідко згадував ім'я самого Е. Гуссерля. Проте сучасний китайський філософ Цзінь Сіпін ${ }^{3}$ переконливо доводить, що на теорію логічної граматики Шень Юдіна справили певний вплив логічні дослідження Е. Гуссерля, особливо що стосується мовних виразів. У

${ }^{1}$ Шень Юдін (沈有鼎, 1908-1989), видатний китайський філософ, фахівець у галузі математичної логіки, професор Університету Цінхуа, Південно-Західного об'єднаного університету і Пекінського університету, науковий співробітник Інституту філософії Академії суспільних наук КНР.

2 Докладно про аналітичну філософію в Китаї див.: [Кіктенко 2018].

${ }^{3}$ Цзінь Сіпін (靳希平, народ. у 1949 році), закінчив філософський факультет Пекінського університету і філософський факультет Тюбінгеського університету (Німеччина) зі ступенем бакалавра і магістра в галузі філософії. На цей час $є$ професором філософії Пекінського університету. Його основні напрями досліджень - давньогрецька філософія, німецька класична філософія та феноменологія. 
1930-ті роки професор Шень Юдін викладав в Університеті Цінхуа, де поряд 3 іншими заняттями проводив семінари 3 феноменології Е. Гуссерля. Згідно із Цзінь Сіпіном першим феноменологом у Китаї слід вважати саме Шень Юдіна [Jin Xiping 2007, 21-32].

Вей Сюн (偉熊, 1911-1994) ${ }^{4}$ після повернення до Китаю в 1941 році все своє життя присвятив вивченню і викладанню західної, перш за все німецької, філософії, а також порівняльному аналізу китайської і західної філософії та встановленню продуктивного обміну між ними. Як зазначає професор Джей Гулдінг, Вей Сюн першим представив у Китаї західну герменевтичну феноменологію5. Надалі переклади Вей Сюна робіт М. Хайдеггера справили величезний вплив на розвиток сучасної китайської філософії. Крім того, саме Вей Сюн об'єднав вивчення філософії М. Гайдеггера з відродженням традиційних ідей даосизму і китайського буддизму, що вже в 1990-ті роки стане важливим напрямком феноменології в Китаї. Що ж стосується Сяо Шиі (蕭師毅, 19111986) 6 , то він працював над Гердерівською енциклопедією і в 1940-ві роки відвідував лекції М. Гайдеггера. Важливо відзначити, що улітку 1946 року саме він допоміг М. Гайдеггеру перекласти німецькою мовою окремі фрагменти знаменитого давньокитайського філософського трактату “Дао де цзін” (“道德 经”) 7 .

У 1961 році Інститут філософії Академії суспільних наук КНР ініціював видання серії “Матеріали із сучасної зарубіжної буржуазної філософії” (“现 代外国资产阶级哲学资料”), до якої, щоправда, мали доступ тільки деякі університетські викладачі та співробітники відділу пропаганди Комуністичної партії Китаю. У першому томі цієї серії був опублікований перший переклад китайською мовою роботи М. Гайдеггера “Що таке метафізика?” (“什么是形 而上学?”; переклад Лян Цуньсю $\left.{ }^{8}\right)$. У 1962 році в тій же серії були видані другий і третій том, де надруковано переклад знаменитої роботи М. Гайдеггера “Лист про гуманізм” (“关于人道主义的书信”; переклад Сюн Вея), а також включено статті, у яких досліджувалася філософська система М. Гайдеггера. У 1963 році опублікована “Антологія екзистенціалізму”, у яку включено і перший переклад китайською мовою робіт М. Гайдеггера - окремих глав "Буття

${ }^{4}$ Вей Сюн (偉 熊, 1911-1994), професор філософії Чунцінського центрального університету (1941), декан філософського факультету Нанкінського центрального університету (1946), професор Літературної академії і декан філософського факультету Університету Тунцзі в Шанхаї (1948), професор і декан філософського факультету Нанкінського університету, професор філософії Пекінського університету, професор і заступник директора Інституту зарубіжної філософії Пекінського університету.

${ }^{5}$ Докладно див.: [Goulding 2004, 116-130].

${ }^{6}$ Сяо Шиі (蕭師毅, також відомий під ім’ям Paul Shih-yi Hsiao, 1911-1986), китайський філософ, викладав в Університеті Фучжень у Тайбеї.

${ }^{7}$ Докладно про інтерес М. Гайдеггера до тексту “Дао де цзін” див.: [Parkes 1987, 93-103].

8 Лян Цуньсю (梁 存 秀, народ. у 1931 р.), відомий також під псевдонімом Лян Чжісюе (梁志 学), випускник Вищої школи філософії Пекінського університету (1956 р.), науковий співробітник Інституту філософії Академії суспільних наук КНР, головний редактор “Філософських перекладів” (“哲学译丛”), головний редактор “Філософії природознавства” (“自然科学哲学问题从刊”), заступник редактора відділу діалектики природи Китайської енциклопедії. В основному займався перекладом $\mathrm{i}$ дослідженнями німецької класичної філософії.

${ }^{9}$ Це глави 4, 6, 9, 14, 26, 27, 38, 40, 41, 53, 65 i 74. 
i час” (“存在与时间”) i “Лист про гуманізм” (переклади Сюн Вея). За загальною редакцією Хун Цяня ${ }^{10}$ в 1964 році видано "Вибрані твори сучасної західної буржуазної філософіi”” (“西方现代资产阶级哲学论著选辑”) [洪谦主 1964], до яких увійшли три роботи М. Гайдеггера в перекладі Сюн Вея - “Що таке метафізика?" (“形而上学 是 什么”), “Буття і час” (розділи 4 і 6) і “До чого поети?” (“诗人何为?”). У 1966 році опублікована збірка “Міркування про гуманізм і людську природу в сучасній західній філософії” (“现代资产阶级哲学 有关人道主义人性论等问题的言论”). У цьому виданні була розміщена стаття “Переклад міркувань Гайдеггера про людяність і гуманізм” (“海德格尔关于人 性, 人道主义的言论摘译”), підготовлена Ван Цзюсіном ${ }^{11}$ у якій використовувалися роботи М. Гайдеггера "Буття і час", “Вчення Платона про істину” і “Лист про гуманізм”. Також у 1960-ті роки з'явилися переклади китайською мовою окремих фрагментів книг Ж.-П. Сартра "Критика діалектичного розумy” (“辩证理性批判”) та “Буття і ніщо” (“存在与虚无”), а також статті західного феноменолога I. Керна "Три шляхи феноменологічної редукції Едмунда Гуссерля". Після ж початку Культурної революції в 1966 році вивчення будьякого напрямку немарксистської філософії в КНР стало неможливим протягом понад десяти років. Проте саме в ці складні роки філософ Лі Ючжен ${ }^{12}$ вивчав у бібліотеці Пекіна томи "Гуссерліани", які туди безкоштовно були відправлені редактором серії, засновником архівного центру Е. Гуссерля в Льовені, бельгійським філософом, монахом-францисканцем, католицьким священиком отцем Германом Лео Ван Бредою (1911-1974). Незважаючи ні на що, у “словнику” китайської філософії цього періоду збереглися такі поняття М. Гайдеггера, як “Seiende” (“即实存”), “Dasein” (“此在”, “亲在”), “Existenz” (“生存”), “das Man” (“常人 或一般人”), “Mitsein” (“共存”), “Mitwelt” (“共同 世界”), “Sorge” (“操心”). У Тайбеї Лі Гуйлян до 100-річчя від дня народження Е. Гуссерля виконав переклад статті філософа, написаної для Британської енциклопедії, а в 1963 році опублікував монографію “Феноменологія Гуссерля" [李貴良 1963] і потім переклад роботи Е. Гуссерля “Філософія як строга наука” (“哲学作为严格的科学”). Засновники нового конфуціанства (新儒家) Тан Цзюнь (唐君毅, 1909-1978) і Моу Цзунсань (牟宗三, 1909-1995) у своїх дослідженнях китайської філософії використовували і компаративний підхід, що, зокрема, виявилося в критичному сприйнятті філософії М. Гайдеггера. Однак у їхніх роботах власне методи феноменології не використовувалися.

У цілому до кінця 1970-х років переклади і дослідження класиків західної феноменології в Китаї були нечисленними та безсистемними.

\section{2. Огляд класичних феноменологічних робіт (кінець 1970-x - середина 1980-х років)}

Повноцінне поширення феноменології та її вивчення в КНР почалося тільки після 1978 року, разом з початком проведення Політики реформ і відкритості.

\footnotetext{
${ }^{10}$ Хун Цян (洪谦, 1909-1992), учень німецько-австрійського філософа-позитивіста М. Шліка, розвивав логічний позитивізм і філософію науки в Китаї.

${ }^{11}$ Ван Цзюсін (王㺵兴, 1916-2003), відомий фахівець у галузі історії західної філософії, перекладач, науковий співробітник Інституту філософії Академії суспільних наук КНР, член Комуністичної партії Китаю.

${ }^{12}$ На цей час Лі Ючжен (李幼蒸, народ. у 1936 р.) живе і працює у США, є дослідником Центру порівняльних досліджень світових цивілізацій Академії суспільних наук КНР, віце-президентом Міжнародного товариства семіотики (IASS) і радником Міжнародного товариства порівняльних досліджень китайської і західної філософії (ISCWP).
} 
У цей час Вей Сюн відновив свої дослідження філософії екзистенціалізму та феноменологічного руху, що перш за все стосувалося перекладів і вивчення робіт М. Гайдеггера. 3 1980-х років Вей Сюн очолював збірник “Вибрані твори філософів-екзистенціалістів” (“存在主义哲学论著选辑”). Окремо необхідно зазначити, що у своїх лекціях і статтях Вей Сюн проводив порівняльний аналіз філософської аргументації К. Маркса і М. Гайдеггера. Під впливом робіт Вей Сюна багато молодих китайських вчених вирушили на навчання до Німеччини і США для вивчення феноменології, передусім філософії М. Гайдеггера. Після їхнього повернення на батьківщину в 1980-х роках феноменологічні дослідження в Китаї суттєво посилилися. Це передусім Ван Цінцзе 王庆节 ${ }^{13}$, Чень Цзяінь 陈嘉映, Яо Чжіхуа 姚治华, Чжан Сяньлун 张祥龙, Сунь Чжоусінь 孙周兴, Пен Фучунь 彭富春, Чень Чуньвень 陈春文, Чжан Юлун 张 汝伦, Ци Сіпін 靳希平 та ін.

У цей період були опубліковані дослідження з феноменології китайських і західних авторів, найраніше 3 яких - це стаття професора Чжуншанського університету Ло Кетіна “Феноменологія Гуссерля - реакція проти сучасних природничих наук” (“胡塞尔 现象学是对现代自然科学发展的反动”) в журналі “Філософські дослідження” (“哲学研究”) [罗克汀 1980, 69-77]. Глави про феноменологію та екзистенціалізм були також включені в наукові видання і підручники з історії філософії. Наприклад, “Огляд відомих сучасних західних філософів” (“现代西方著名哲学家书评”), підготовлений за загальною редакцією відомого китайського філософа, президента Китайської асоціації вивчення сучасної зарубіжної філософії Ду Женьчжі (杜任之, 1905-1988), містив глави про Е. Гуссерля, М. Гайдеггера, Ж.-П. Сартра, М. Шелера та М. Мерло-Понті [杜任之 1980]. Інша велика робота - "Сучасна західна філософія” (“现代西方哲学”), видана в 1981 році за редакцією професора Фуданського університету, заступника президента Китайської асоціації вивчення сучасної зарубіжної філософії Лю Фантуна 刘放 桐, - містить глави про феноменологію та екзистенціалізм [刘放桐 1981]. Гуань Цзиін 關子尹 та Чжан Цаньхуей 張燦輝 після успішного захисту на початку 1980 -х років докторських дисертацій з філософії М. Гайдеггера і Е. Гуссерля в німецьких університетах почали викладати феноменологію в Китайському університеті (Гонконг). У Куньжу 乌覑如 здобув освіту в Тайванському та Мюнхенському університетах і після цього викладав у різних університетах і навчальних закладів Тайбея. Одна $з$ його важливих робіт - це “Феноменологічні нариси” (“现象学论文集”) [鸟昆如 1981].

3. Переклад китайською мовою вибраних класичних феноменологічних робіт (кінець 1980-х - середина 1990-х років)

У середині 1980-х років спостерігається зростання інтересу китайських філософів до феноменології та екзистенціалізму, що виявилося насамперед у перекладі китайською мовою провідних представників цього напрямку західної філософії - Е. Гуссерля, М. Гайдеггера, М. Шелера і Ж.-П. Сартра.

Так, переклад китайською мовою “Ідеї феноменології” Е. Гуссерля [胡塞尔 1986] був перевиданий тричі і досяг загального тиражу 130 тис. екземплярів.

${ }^{13}$ Ван Цзіцзе (王庆节), китайський філософ, здобув освіту в Тулейнському університеті (США), професор Китайського університету (Гонконг), спеціалізується на сучасній європейській філософії, порівняльній філософії “Схід - Захід” і моральній філософії. 
Трохи пізніше були видані переклади інших праць та неопублікованих рукописів Е. Гуссерля: “Криза європейських наук і трансцендентальна феноменологія” [胡塞尔 1988], “Ідеї до чистої феноменології та феноменологічної філософії. Книга перша. Загальний вступ у чисту феноменологію” з післямовою Е. Гуссерля 1930 року [胡塞尔 1992]; “Логічні дослідження. Том 1. Пролегомени до чистої логіки” [胡塞尔 1994] та ін. Важливо відзначити, що проведена колосальна перекладацька робота дала свої плоди, і вже в 1990-ті роки в Китаї з'явилися численні монографії та близько сотні статей 3 феноменології Е. Гуссерля.

М. Гайдеггер, в основному першого періоду творчості, став широковідомий у Китаї завдяки Вей Сюну, який у цей час викладав у Пекінському університеті. У перекладі Чень Цзяіня ${ }^{14}$ і Ван Цінцзе ${ }^{15}$ під загальним керівництвом Вей Сюна китайською мовою було видано "Буття і час" - спочатку в Пекіні в 1987 році [海德格尔 1987], а потім у Тайбеї в 1990 році [海德格尔 1990a]. Крім того, вийшли переклади “Ніцше” [海德格尔 1990b], “Гайдеггер про Ніцше: сильна воля як мистецтво” (переклад Цинь Вея 秦伟, Юй Хуна 余 虹) [海德格尔论尼采... 1990], “Поезія, мова, думка” [诗•语言・思 1990], “Поетика. Зібрання творів” [海德格尔 1992], “Людина, поетично настроєна” (збірка висловлювань М. Гайдеггера) [海德格尔 1995] та ін.

Китайською мовою були перекладені деякі праці німецького філософафеноменолога і соціолога, одного з основоположників філософської антропології М. Шелера - “Становище людини в космосі” [舍勒 1989], “Відновлення чесноти”, “Християнська ідея любові і справжній мир”, “Порядок любові” [舍勒 1989].

Ж.-П. Сартр є найвідомішим феноменологом у Китаї, що пояснюється, поперше, його близькістю до марксизму i, по-друге, тим, що від початку Політики реформ і відкритості в 1978 році сартрівська ідея свободи стала близька багатьом молодим китайським інтелектуалам. У цей період китайською мовою були перекладені такі роботи французького філософа: “Буття і ніщо” [萨 特 1987], “Екзистенціалізм - це гуманізм” [萨特 1988], “Слова” [萨特 1989].

Крім перекладів праць класиків феноменології, з’явилися переклади критичних досліджень західних учених [斯坦纳 1988; 斯坦纳 1989; 鲁特凯维奇 1989; 绍伊博尔德 1993] та оригінальні дослідження китайських філософів [俞 宣孟 1989; 项退结 1989; 余虹 1991; 宋祖良 1993; 叶秀山 1988; 熊伟 1994; 孙 周兴 1994; 涂成林 1994; 靳希平 1995; 陈嘉映 1995; 张汝伦 1995]. Також у цей період відбулася інституталізація феноменології в Китаї, що передусім було пов'язано з організацією викладання і вивчення цього напрямку західної думки в китайських університетах. Це Південно-Східний університет у Нанкіні, професор Ні Лянкан 倪梁康; Пекінський університет, професор Ду Сяожень 杜小真 i професор Цзінь Сіпін 靳希平; Фуданський університет у Шанхаї,

14 Чень Цзяінь (陈嘉映, народ. у 1952 р.), китайський філософ, дослідник філософiї М. Гайдеггера та філософії мови, на цей час є завідувачем відділу зарубіжної філософії Пекінського педагогічного університету.

${ }^{15}$ Ван Цінцзе (王庆节), китайський філософ, основними напрямками досліджень якого є сучасна континентальна філософія, філософія М. Гайдеггера, герменевтика, епістемологія, порівняльна філософія “Схід - Захід”, етика, німецька філософія та ін. Друкується в таких великих наукових журналах, як "International Philosophical Quarterly”, “Philosophy East \& West”, “Китайський журнал соціальних наук” (“中国社会科 学”), “Китайська феноменологія і філософський огляд” (“中国现象学与哲学评论”). 
професор Чжан Цінсюн 张庆熊. Важливим етапом у цьому процесі стало створення в 1994 році завдяки зусиллям професора Ні Лянкана і за підтримки європейських та американських феноменологів Китайського товариства феноменології (中国现象学会). Це товариство проводить щорічні конференції, у яких беруть участь вчені з Китаю і західних країн, а також видає щорічник “Феноменологічні та філософські дослідження в Китаї” (“中国现象学评论”) 3 особливим акцентом на виданні перекладів китайською мовою праць представників західної феноменології. При цьому велика частина досліджень членів Китайського товариства феноменології присвячена філософії М. Гайдеггера. Один з найвідоміших західних дослідників Е. Гуссерля, швейцарський феноменолог Ісо Керн, який редагував кілька томів “Гуссерліани”, почав активно співпрацювати з китайськими вченими. Крім власне розвитку феноменології, у китайських університетах і наукових центрах розпочався продуктивний процес взаємодії феноменології з іншими філософськими напрямки і науковими дисциплінами.

Серед китайських студентів, які навчалися в цей період за кордоном, слід згадати Лю Гоїна ${ }^{16}$, який у 1993 році захистив докторську дисертацію з філософії М. Мерло-Понті в Сорбоннському університеті (Париж) і після цього почав викладати в Китайському університеті (Гонконг).

4. Переклад китайською мовою вибраних праць і повного зібрання творів класиків феноменології, оригінальні феноменологічні дослідження (середина 1990-х років - теперішній час)

Заснування у квітні 1996 року Гонконзького товариства феноменології, а також активізація наукових обмінів між берегами Тайванської протоки, безумовно, позитивно вплинули на розвиток феноменології в Китаї, бо в Гонконзі і Тайвані феноменологія на той момент була представлена більш розвинуто. У цей період було продовжено роботу 3 перекладу китайською мовою робіт Е. Гуссерля: “Вибрані праці Гуссерля” [胡塞尔选集 1997], “Філософія як строга наука" [胡塞尔 1999a], “Логічні дослідження” [胡塞尔 1999b; 胡塞尔 1999c], “Досвід і судження” [胡塞尔 1999d], “Феноменологія внутрішньої свідомості часу” [胡塞尔 2000], “Криза європейських наук і трансцендентальна філософія” [胡塞尔 2001], “Декартові медитації” [胡塞尔 2002c], “Феноменологія життєвого світу” [胡塞尔 2002a], “Загальні питання етики та аксіології” [胡塞尔 2002b]. На цей час Національний фонд суспільних наук Китаю (国家 社会科学基金会) здійснює підтримку проекту “Китайський переклад робіт Гуссерля”, яким керує Ні Лянкан. Також з'явилися переклади китайською мовою провідних дослідників феноменології Е. Гуссерля (Т. де Бур, Х. Шпігельберг, Г. Шмітц, В. Веларді, Х. Імамура, Д. Д. Сміт), що значно розширило уявлення китайських філософів і вчених про сучасний розвиток феноменологічного руху у світі.

16 Лю Гоїн (劉國英), професор, директор магістерської програми філософії на філософському факультеті Китайського університету в Гонконзі, головний редактор і засновник китайськомовного журналу “Феноменологія і гуманітарні науки” (3 2004 року), директор Фонду Едвіна Чена Азіатського центру феноменології (3 2010 року), один із засновників Східно-азіатської дослідницької мережі (Феноменологія в Східно-азіатському колі) (з 2002 року), організатор симпозіуму Phaenomenologica Asiatica i майстер-класів з феноменології для азіатських вчених. 
Професору Сунь Чжоусіню належить найбільше число перекладів китайською мовою робіт М. Гайдеггера. За його загальною редакцією були підготовлені “Вибрані твори Гайдеггера" [海德格尔选集 1996], куди увійшло 42 твори німецького мислителя, 25 з яких були перекладені самим Сунь Чжоусінем, а також його особисті переклади: “Гельдерлін і сутність поезіі” [海德 格尔 2000b], “Ніцше” [海德格尔 2002] та ін. [海德格尔 1997; 海德格尔 2000a; 海德格尔与有限性思想 2002; 海德格尔 2004; 海德格尔存在哲学 2004; 形式显 示的现象学... 2004; 演讲与论文集 2005]. У 1996 і 1999 роках було видано два переклади “Вступу до метафізики” (Сюн Вея і Ван Цінцзе [海德格尔 1996] та Ян Кайчуна [海德格尔 1999b]). У 1999 році вийшло друге, а у 2006 році третє доопрацьоване видання перекладу китайською мовою роботи М. Гайдеггера “Буття і час" (переклад Чень Цзяіня і Ван Цінцзе) [海德格尔 1999a; 海德格尔 2006]. Окрім того, китайською мовою було перекладено цілу низку важливих монографій західних учених, у яких досліджуються різні аспекти філософії М. Гайдеггера та екзистенціалізму в цілому [科克尔曼斯 1996; 布托 1996; 比 梅尔 1996; 萨弗兰斯基 1998; 沃林 2000; 法里亚斯 2000; 爱丁格 2000; 高田珠 树 2001; 贝勒尔 2001; 约翰逊 2002 年; 扬 2002; 克莱芒 2002; 梅依 2003; 科林 斯 2005; 库尔珀 2004; 罗森 2004; 沃林 2005; 默里斯 2005; 艾伯林 2006; 巴姆 巴赫 2007; 马尔霍尔 2007; 海德格尔年鉴2009]. Важливо, що, крім перекладів, у цей період видано низку робіт китайських учених, у яких досліджується філософія М. Гайдеггера [张祥龙 1996; 张灿辉 1996; 滕守尧 1996; 黄裕生 1997; 张祥龙 1998; 刘永富 2000; 彭富春 2000; 张祥龙 2001; 夏汉苹 2001; 刘敬鲁 2001; 胡自信 2002; 李文堂 2002; 周民锋 2002; 王金林 2002; 李智 2003; 柯小刚 2004; 钟华 2004; 张贤根 2004; 张文喜 2004; 刘旭光 2004; 王庆节 2004; 郝文杰 2004; 崔唯航 2005; 范玉刚 2005; 余虹 2005; 王恒 2006; 赵卫国 2006; 韩潮 2007].

У цей час феноменологія в Китаї перебуває в основному на стадії сприйняття цього напрямку західної думки і формування власних феноменологічних досліджень, у яких Джулія Янсен і Цай Веньцзін виділяють три течії [Jansena 2018, 3-4]:

1) актуальність феноменології для конфучіанства $і$ буддизму. У порівняльних дослідженнях приділяється увага, наприклад, феноменології і неоконфуціанській школі “вчення про серце” (心學, xīn хие́). Шляхом об”єднання гуссерліанського поняття "свідомості” і неоконфуціанської етики "розуму” відбувається взаємозбагачення західної і китайської філософії, а кінцевою метою цього процесу визначено створення “феноменологічної школи розуму”. Наприклад, Ні Лянкан намагається виробити етику у світлі як гуссерліанської феноменології, так і конфуціанської доктрини свідомості. Водночас китайський буддизм, що суттєво вплинув на конфуціанство, стає важливим джерелом для дослідження паралелей між феноменологією і буддизмом (особливо це стосується “вчення про свідомість” (唯识, wéi shi) у буддійській школі Йогочара). Наприклад, Чжан Цінсюн проводить порівняльне дослідження буддійського світогляду чільного представника нового конфуціанства Сюн Шилі (熊十力, 1885-1968) і феноменології Е. Гуссерля [张庆熊 1995]. Ван Цзіцзе вивчає можливості застосування герменевтики і філософії М. Гайдеггера для сучасної інтерпретації конфуціанства і даосизму [王庆节 2004]. Таким чином, у рамках цієї течії відбувається конструктивна для розвитку сучасної китайської філософії взаємодія традиційних китайських ідей і феноменологічного руху; 
2) феноменологія в історичному контексті. Дослідження таких гуссерліанських понять, як “інтенціональність”, “час", “трансцендентність” у співвідношенні з корелюючими поняттями Р. Декарта, Д. Юма, І. Канта, Ф. Брентано та ін. Останнім часом китайські філософи дедалі більше уваги приділяють концепціям послідовників і “єретичних" наступників засновника феноменології (М. Гайдеггер, О. Фінк, М. Мерло-Понті, Ж.-П. Сартр, Ж. Дерріда, Е. Левінас і Ж.-Л. Маріон). При цьому найчастіше здійснюється порівняльний аналіз ідей Е. Гуссерля та М. Гайдеггера: Лю Сяолі, “Філософська програма Геделя i феноменологія Гуссерля" [Liu Xiaoli 2010, 33-45]; Чжан Цінсюн, “Гайдеггер і феноменологія Гуссерля" [张灿辉 1996]; Ван Веньшен, “Гуссерль і Гайдеггер” [汪文聖 1997]; Ні Лянкан, “Гуссерль і Гайдеггер: зустріч і розставання у Фрайбурзі” [倪梁康 2016]; Фан Сянхун, “Час і буття: основні проблеми феноменології Гуссерля і Гайдеггера" [方向红 2014]. Професор Пекінського університету У Цзендін 吴增定 досліджує питання про те, наскільки гуссерліанська феноменологія залишається в рамках традиційної метафізики, як стверджували М. Гайдеггер і Ж. Дерріда [Wu Zengding 2018, 21-34]. Лян Гаінь доводить, що розуміння Е. Гуссерлем чуттєвого досвіду розходиться з традиційними концепціями, але все ж піддається “двійковій схемі" (чуттєвий досвід потребує ноетичного передчуття) [Leung Ka-wing 2018, 35-49]. Ло Лечжунь досліджує співвідношення буття і часу у Платона, Августина і Гуссерля [Lee Chun Lo 2018, 50-61]. Чжен Піжуй розглядає найбільш спірний аспект теорії інтерсуб'єктивності Гуссерля - що мотивує досвід іншого (в розумінні автора, бажання або “наукове прагнення” натуралізує власне тіло оптимальним чином, і це виводить трансцендентальний суб' єкт за межі власної сфери й дає змогу увійти іншому) [Zheng Pirui 2018, 62-73]. Hi Лянкан розмірковує про феноменологічно-онтологічні виміри філософії істоpiї та проблеми історії у філософії Е. Гуссерля і М. Гайдеггера. Як відомо, Е. Гуссерль ніколи системно не викладав свої думки про історію у своїх опублікованих роботах, і тому його часто називають “неісторичним" філософом. Проте Ні Лянкан доводить, що В. Дільтей, Йорк фон Вартенбург, Е. Гуссерль, М. Гайдеггер та Г.-Г. Гадамер вплинули на формування найважливішої традиції в історії філософії XX століття, а саме феноменолого-онтологічної філосоpiï icmopiï [Ni Liangkang 2018, 7-20]. Цай Веньцзін досліджує концепції "реальності" в Е. Гуссерля і Дж. Макдауелла з метою розуміння “сумісності і напруги” ідеалізму та реалізму здорового глузду [Cai Wenjing 2018, 88-99]. Лю Гоїн переклав китайською мовою низку праць Гуссерля, Гайдеггера, Сартра, Мерло-Понті, Левінаса, Рікьора і до того ж опублікував близько ста робіт, написаних китайською, англійською та французькою мовами, з феноменології, сучасної французької філософії, постмодернізму і міжкультурного взаєморозуміння. Особливо слід відзначити його монографії "Логічні дослідження Гуссерля в новому столітті: західна і китайська перспективи” [Lau Kwok-Ying 2007], “Ідентичність та інакшість: феноменологія та культурні традиції” [Lau Kwok-Ying 2010], “Феноменологія та людський досвід” [Lau Kwok-Ying 2012], "Прикордонний перетин: феноменологія, міжкультурність і міждисциплінарність" [Lau Kwok-Ying 2014]. У цей період великий внесок був зроблений Ван Цзіцзе, який є співредактором тридцяти-томного видання праць М. Гайдеггера китайською мовою. Крім того, ним були також опубліковані критичні дослідження: “Гайдеггер і початок філософії” [王庆节 2015], “Гайдеггер” [王庆节 2017]; 
3) Діалог між феноменологією та аналітичною філософією. Незважаючи на загальноприйняту точку зору про "розділ” між “континентальною” та аналітичною філософією, китайські вчені вважають природною їхню взаємодію. Обгрунтовується це тим, що обидва напрямки мають кілька загальних основних проблем: можливість пізнання, поняття “інтенціональність” і “самість”, теорія тілесності, чужа свідомість. При цьому одні китайські вчені прагнуть зробити феноменологію більш зрозумілою і більш актуальною для аналітичної філософії, інші - інтерпретують феноменологічні тексти за допомогою аналітичних аргументів. Наприклад, Лі Чжунвей поміщає гуссерліанське поняття “інтенціональність” у ширший контекст, який включає в себе дискусії 3 традиції аналітичної філософії [李忠伟 2013; Li Zhongwei 2018].

Феноменологічний рух існує вже понад сто років, проте китайські вчені до сьогодні ще не досягли світового рівня розвитку в цьому напрямку філософських досліджень. Однак, як бачимо, протягом останніх десятиріч була зроблена титанічна робота 3 перекладу китайською мовою фундаментальних феноменологічних праць та досить успішно розвивається власна феноменологічна школа в наукових та освітніх центрах Китаю. Все це демонструє успішну подальшу інтеграцію до світової науки китайських філософів, які до того ж формують власний погляд на розуміння структури свідомості людини.

\section{ЛІТЕРАТУРА}

Кіктенко В. О. Огляд історії аналітичної філософії в Китаї (XX - початок ХХІ століття) // Східний світ, 2018, № 2.

Goulding J. Xiong Wei: Chinese Philosophy and Hermeneutic Phenomenology // Gate of Philosophy 哲學門, Beijing University's Journal of Philosophy special $\mathbf{9 0}^{\text {th }}$ anniversary of the Department of Philosophy, 2004, Vol. 5.

Hsiao, Paul Shih-yi. Heidegger and Our Translation of the Tao Te Ching // Parkes G. (Ed.). Heidegger and Asian Thought. Honolulu, 1990.

Jansena J., Cai Wenjing. Husserlian Phenomenology: Current Chinese Perspectives // Comparative and Continental Philosophy, 2018, Vol. 10, No 1.

Jin Xiping. Youding Shen: The First Phenomenologist in China // Lau KwokYing, Drummond J. J. (Eds.). Husserl's Logical Investigations in the New Century: Western and Chinese Perspectives. Dordrecht, 2007.

Kern I. China // Lester Embree, et al (Eds.). Encyclopedia of Phenomenology. Dordrecht, 2007.

Lau Kwok-Ying, Drummond J. J. (Eds.). Husserl's Logical Investigations in the New Century: Western and Chinese Perspectives. Dordrecht, 2007.

Lau Kwok-Ying, Cheung Chan-Fai, Kwan Tze-Wan. Identity and Alterity: Phenomenology and Cultural Traditions. Würtzburg, 2010.

Lau Kwok-ying, Yu Chung-chi. Phenomenology and Human Experience. Traugott, 2012.

Lau Kwok-ying, Yu Chung-Chi. Border-crossing: phenomenology, interculturality and interdisciplinarity. Würzburg, 2014.

Lee Chun Lo. Time, the Image of Absolute Logos: A Comparative Analysis of the Ideas of Augustine and Husserl // Comparative and Continental Philosophy, 2018, Vol. 10, No 1.

Leung Ka-wing. Husserl's Notion of Sensation and Merleau-Ponty's Critique // Comparative and Continental Philosophy, 2018, Vol. 10, No 1.

Liu Xiaoli. Gödel's philosophical program and Husserl's phenomenology // Synthese, 2010, Vol. 175, No 1. 
Li Zhongwei. From the Naturalistic to the Transcendental Conception of Intentionality // Comparative and Continental Philosophy, 2018, Vol. 10, No 1.

Ni Liangkang, Iso Kern. Phänomenologische Forschungen in China // Phänomenologische Forschungen Neue Folge, 1997, Vol. 2, No 2.

Parkes G. Heidegger and Asian Thought. Honolulu, 1987.

$W u$ Zengding. The Problem of Origin in Husserl's Phenomenology // Comparative and Continental Philosophy, 2018, Vol. 10, No 1.

Zheng Pirui. What Awakens the Alien experience: starting from the incorporation of the lived body // Comparative and Continental Philosophy, 2018, Vol. 10, No 1.

艾伯林・汉斯。自由、平等、必死性。上海，2006.

爱丁格•阿丽斯贝塔。阿伦特与海德格尔。沈阳，2000.

巴姆巴赫。海德格尔的根。上海, 2007.

贝勒尔・恩斯特。尼采、海德格尔与德里达。北京，2001.

比梅尔。海德格尔。北京, 1996.

布托•阿兰。海德格尔。北京，1996.

陈嘉映。海德格尔哲学概论。北京, 1995.

崔唯航, 张羽佳。本真存在的路标-马丁・海德格尔。保定, 2005.

杜任之, 编。现代西方著名哲学家述评。北京, 1980 .

法里亚斯・维克托。海德格尔与纳粹主义。北京, 2000 .

樊 炳 清 , 编。哲学辞典。上海, 1926.

范玉刚。睿思与岐误: 一种对海德格尔技术之思的审美解读。北京, 2005 .

方向红。时间与存在: 胡塞尔与海德格尔现象学的基本问题。北京, 2014.

高田珠树。海德格尔: 存在的历史。石家庄，2001.

海德格尔。存在与时间。北京, 1987 .

海德格尔。存在与时间。台北，1990a.

海德格尔。论尼。石家庄, $1990 b$.

海德格尔。海德格尔诗学文集。武汉, 1992.

海德格尔。人, 诗意地安居。上海, 1995 .

海德格尔。形而上学导论。北京, 1996.

海德格尔。林中路。上海，1997.

海德格尔。存在与时间。北京，1999a.

海德格尔。形而上学导论。北京, $1999 b$.

海德格尔。路标。北京, $2000 a$.

海德格尔。荷尔德林诗的阐释, 北京, $2000 \mathrm{~b}$.

海德格尔。尼采, 上、下册. 北京, 2002 .

海德格尔。在通向语言的途中。北京, 2004 .

海德格尔。存在与时间。北京，2006.

海德格尔选集，上、下册，上海， 1996.

海德格尔与有限性思想。北京, 2002 .

海德格尔存在哲学。海口, 2004.

海德格尔论尼采：作为艺术的强力意志。石家庄，1990.

《海德格尔年鉴》第一卷: 海德格尔与其思想的开端。北京, 2009 .

韩潮。海德格尔与伦理学问题。上海, 2007.

郝文杰。石涛画学与海德格尔艺术哲学研究：本体论与创作论之比析。天 津, 2004.

洪谦主编。西方现代资产阶级哲学论著选辑。北京， 1964 .

胡塞尔。现象学的观念。上海, 1986 . 
胡塞尔。欧洲科学危机和超验现象学。上海, 1988.

胡塞尔。纯粹现象学通论-第一卷。北京, 1992.

胡塞尔。逻辑研究-第一卷-纯粹逻辑学导论。台北, 1994.

胡塞尔选集。上海, 1997.

胡塞尔。哲学作为严格的科学。北京, 1999a.

胡塞尔。逻辑研究-第二卷, 第一部分一现象学与认识论研究。台北, $1999 b$.

胡塞尔。逻辑研究-第二卷, 第二部分一现象学与认识论研究。台北, $1999 c$.

胡塞尔。经验与判断。北京, 1999d.

胡塞尔。内在时间意识现象学。北京, 2000 .

胡塞尔。欧洲科学的危机与超越论的现象学。北京, 2001 .

胡塞尔。生活世界现象学。上海, $2002 a$.

胡塞尔。伦理学与价值论的基本问题。北京, $2002 b$.

胡塞尔。笛卡尔式的沉思。北京, $2002 c$.

胡自信。黑格尔与海德格尔。北京, 2002 .

黄裕生。时间与永恒：论海德格尔哲学中的时间问题。北京， 1997 .

靳希平。海德格尔早期思想研究。上海, 1995.

科克尔曼斯・约瑟夫。海德格尔的〈存在与时间〉对作为基本存在论的此在 的分析 / 陈小文等译, 商务印书馆。北京, 1996.

克莱芒・卡特琳。马丁与汉娜：海德格尔和他的妻子及情人。北京， 2002 .

科林斯・杰夫。海德格尔与纳粹。北京, 2005 .

柯小刚。海德格尔与黑格尔时间思想比较研究。上海, 2004 .

库尔珀著・大卫。纯粹现代性批判：黑格尔、海德格尔及其以后。北京, 2004.

梅依著・莱因哈德。海德格尔与东亚思想。北京，2003.

李貴良。胡塞爾現象學。台北, 1963.

李文堂。真理之光：费希特与海德格尔论 SEIN。南京， 2002.

李智。论海德格尔的现代性批判：另一种后现代主义。北京，2003.

刘放桐。现代西方哲学。北京, 1981 .

刘敬鲁。海德格尔人学思想研究。北京, 2001 .

刘旭光。海德格尔与美学。上海, 2004.

刘永富。胡塞尔现象学、海德格尔本是学引论-从所知学的角度重新解读

胡塞尔与海德格尔。西安, 2000 .

李忠伟。回到现象学的意向性理论。北京, 2013 .

罗克汀。胡塞尔现象学是对现代自然科学发展的反动 // 哲学研究, 1980,

No 3.

罗森。诗与哲学之争: 从柏拉图到尼采、海德格尔。北京, 2004 .

鲁特凯维奇。从弗洛伊德到海德格尔存在精神分析评述。北京， 1989 .

马尔霍尔。海德格尔与《存在与时间》。桂林, 2007.

默里斯・马克・弗罗芒。海德格尔诗学。上海，2005.

倪梁康。胡塞尔与海德格尔。北京, 2016 .

彭富春。无之无化-论海德格尔思想道路的核心问题。上海, 2000 .

萨弗兰斯基・吕。海德格尔传-来自德国的大师。北京，1998.

萨特。存在与虚无。北京, 1987 .

萨特。存在主义是一种人道主义。上海, 1988 .

萨特。词语。上海, 1989 .

绍伊博尔德・冈特。海德格尔分析新时代的科技。北京, 1993.

舍勒。爱的秩序。香港, 1994 .

沈有鼎。沈有鼎文集。北京, 1992 .

诗•语言・思。北京, 1990 . 
斯坦纳·乔治。存在主义祖师爷：海德格尔。长沙，1988.

斯坦纳•乔治。海德格尔。北京，1989.

宋祖良。拯救地球和人类未来-海德格尔的后期思想。北京, 1993.

孙周兴。说不可说之神秘：海德格尔后期思想研究。上海, 1994.

涂成林。现象学的使命: 从胡塞尔、海德格尔到萨特。广州, 1994.

滕守尧。海德格。台北, 1996.

王恒。时间性、自身与他者：从胡塞尔、海德格尔到列维纳斯。南京, 2006.

王金林。世界历史意义的本质道说一从海德格尔的解读看马克思哲学的当 代性。上海，2002.

王庆节。解释学、海德格尔与儒道今释。北京, 2004 .

王庆节。海德格尔与哲学的开端。北京, 2015 .

王庆节。海德格尔。北京, 2017 .

汪文聖。胡塞爾與海德格。台北, 1997.

沃林・理查德。存在的政治：海德格尔的政治思想。北京，2000.

沃林・理查德。德格尔的弟子: 阿伦特、勒维特、约纳斯和马尔库塞。南 京, 2005.

邬昆如。现象学论文集。台北，1981.

夏汉苹。海德格尔传。武汉，2001.

项退结。海德格。台北, 1989.

形式显示的现象学 - 海德格尔早期弗莱堡文选。上海, 2004 .

熊伟，编。现象学与海德格。台北，1994年。

楊人梗。現象學概論 // 民铎, 1929, Vol. 10, No 1.

扬・朱利安。海德格尔哲学纳粹主义。沈阳, 2002.

演讲与论文集。北京, 2005 .

叶秀山。思・史・诗-现象学和存在哲学研究。北京, 1988 .

余虹。思与诗的对话：海德格尔诗学引论。北京，1991.

余虹。艺术与归家：尼采・海德格尔・福柯。北京，2005.

俞宣孟。现代西方的超越思考：海德格尔的哲学。上海, 1989 .

约翰逊・帕特里夏・奥坦伯德。海德格尔。北京, 2002 .

张灿辉。海德格尔与胡塞尔现象学。台北, 1996.

张庆熊。熊十力的新唯识论与胡塞尔的现象学。上海, 1995 .

张汝伦。海德格尔与现代哲学。上海, 1995.

张文喜。颠覆形而上学：马克思和海德格尔之论。北京，2004.

张贤根。存在・真理・语言：海德格尔美学思想研究。武汉, 2004.

张祥龙。海德格尔思想与中国天道 - 终极视域的开启与交融。北京, 1996.

张祥龙。海德格尔传。石家庄，1998.

张祥龙。从现象学到孔夫子。北京, 2001 .

张祥龙。现象学思潮在中国。北京, 2011 .

赵卫国。海德格尔的时间与时・间性问题研究。北京，2006.

钟华。从逍遥游到林中路：海德格尔与庄子诗学思想比较。北京， 2004 .

周民锋。走向大智慧：与海德格尔对话。成都， 2002 .

\section{REFERENCES}

Aibolin•Hansi. (2006), Ziyou, pingdeng, bisi xing, Huadong shifan daxue chuban she, Shanghai. (in Chinese).

Aidingge•Alisibeita. (2000), Alunte yu Haidegeer, Chunfeng wenyi chuban she, Shenyang. (in Chinese).

Bamubahe. (2007), Haidegeer de gen, Shanghai shudian chuban she, Shanghai. (in Chinese). 
Beileer•Ensite. (2001), Nicai, Haidegeer yu Delida, Shehui kexue chuban she, Beijing. (in Chinese).

Bimeier. (1996), Haidegeer, Shangwu yin shuguan, Beijing. (in Chinese).

Butuo, Alan. (1996), Haidegeer, Shangwu yin shuguan, Beijing. (in Chinese).

Chen Jiaying. (1995), Haidegeer zhexue gailun, Sanlian shudian, Beijing. (in Chinese).

Cui Weihang, Zhang Yujia. (2005), Ben zhen cunzai de lubiao - Mading $• H a i-$ degeer, Hebei daxue chuban she, Baoding. (in Chinese).

Du Renzhi, bian. (1980), Xiandai xīfāng zhùmíng zhéxué jiā shùpíng, Sanlian shudian, Beijing.

Fan Bingqing, bian. (1926), Zhexue cidian, Shangwu yin shuguan, Shanghai. (in Chinese).

Fan Yugang. (2005), Rui Si yu qiwu: Yi zhong dui Haidegeer jishu zhi si de shenmei jiedu, Zhongyang bianyi chubanshe, Beijing. (in Chinese).

Fang Xianghong. (2014), Shijian yu cunzai: Husaier yu Haidegeer xianxiang xue de jiben wenti, Shangwu yin shuguan, Beijing.

Faliyasi•Weiketuo. (2000), Haidegeer yu nacui zhuyi, Shishi chuban she, Beijing. (in Chinese).

Gangte Shaoyiboerde. (1993), Haidegeer fenxi xin shidai de keji, Beijing zhongguo shehui kexue chuban she, Beijing. (in Chinese).

Gaotianzhushu. (2001), Haidegeer: Cunzai de lishi. Hebei jiaoyu chuban she, Shijiazhuang. (in Chinese).

Goulding J. (2004), "Xiong Wei: Chinese Philosophy and Hermeneutic Phenomenology", Gate of Philosophy, Beijing University's Journal of Philosophy special 90 th anniversary of the Department of Philosophy, Vol. 5, pp. 116-130.

Haidegeer. (1987), Cunzai yu shijian, Sanlian shudian, Beijing. (in Chinese).

Haidegeer. (1990), Cunzai yu shijian, Jiuda wenhua gongsi, guiguan tushu gongsi, Taibei. (in Chinese).

Haidegeer. (1990), Haidegeer lun nicai, Hebei renmin chubanshe, Shijiazhuang. (in Chinese).

Haidegeer. (1992), Haidegeer shi xue wenji, Huazhong shifan daxue chubanshe, Wuhan. (in Chinese).

Haidegeer. (1995), Ren, shiyi di anju, Shanghai yuandong chubanshe, Shanghai. (in Chinese).

Haidegeer. (1996), Xing'ershangxue daolun, Shangwu yin shuguan, Beijing. (in Chinese).

Haidegeer. (1997), Lin zhonglu, Shanghai yiwen chubanshe, Shanghai. (in Chinese).

Haidegeer. (1999), Xing'ershangxue daolun, Zhongguo shehui chubanshe, Beijing. (in Chinese).

Haidegeer. (2000), Heerdelin shi de chanshi, Shangwu yin shuguan, Beijing. (in Chinese).

Haidegeer. (2000), Lubiao, Shangwu yin shuguan, Beijing. (in Chinese).

Haidegeer. (2002), Nicai, shang, xia ce, Shangwu yin shuguan, Beijing. (in Chinese).

Haidegeer. (2004), Zai tong xiang yuyan de tuzhong, Shangwu yin shuguan, Beijing. (in Chinese).

Haidegeer yu youxian xing sixiang (2002), Huaxia chuban she, Beijing. (in Chinese). 
Haidegeer xuanji. (1996), shang, xia ce, Shanghai sanlian shudian, Shanghai. (in Chinese).

Haidegeer cunzai zhexue (2004), Jiuzhou chuban she, Haikou. (in Chinese).

Haidegeer lun Nicai: Zuowei yishu de qiangli yizhi. (1990), Hebei renmin chuban she, Shíjiāzhuāng. (in Chinese).

"Haidegeer nianjian" di yi juan: Haidegeer yuqi sixiang de kaiduan, (2009), Shangwu yin shuguan, Beijing. (in Chinese).

Han Chao. (2007), Haidegeer yu lunli xue wenti, Tongji daxue chubanshe, Shanghai. (in Chinese).

Hao Wenjie. (2004), Shi Tao huaxue yu Haidegeer yishu zhexue yanjiu: Benti lun yu chuangzuo lun zhi bi xi, Tianjin renmin meishu chuban she, Tianjin. (in Chinese).

Hong Qianzhu bian. (1964), Xifang xiandai zichan jieji zhexue lunzhu xuanji, Beijing. (in Chinese).

Hsiao, Paul Shih-yi. (1990), "Heidegger and Our Translation of the Tao Te Ching," in Parkes G. (Ed.), Heidegger and Asian Thought, University of Hawaii Press, Honolulu. nese).

Hu Zixin. (2002), Heigeer yu Haidegeer, Zhonghua shuju, Beijing. (in Chi-

Huang Yusheng. (1997), Shijian yu yongheng: Lun Haidegeer zhexue zhong de shijian wenti, Shehui kexue wenxian chubanshe, Beijing. (in Chinese).

Husaier. (1986), Xianxiang xue de guannian, Shanghai yiwen chuban she, Shanghai. (in Chinese).

Husaier. (1988), Ouzhou kexue weiji he chao yan xianxiang xue, Shanghai yiwen chuban she, Shanghai. (in Chinese).

Husaier. (1992), Chuncui xianxiang xue tonglun - di yi juun, Shangwu yin shuguan, Beijing. (in Chinese).

Husaier. (1994), Luoji yanjiu - di yi juan-chuncui luoji xue daolun, Shibao wenhua chuban qiye gongsi, Taibei. (in Chinese).

Husaier xuanji (1997), Shanghai sanlian shudian, Shanghai. (in Chinese)

Husaier. (1999), Zhexue zuowei yange de kexue, Shangwu yin shuguan, Beijing. (in Chinese).

Husaier. (1999), Luoji yanjiu - di er juan, di yibufen-xianxiang xue yu renshilun yanjiu, Shibao wenhua chuban qiye gongsi, Taibei. (in Chinese).

Husaier. (1999), Luoji yanjiu - di er juan, di er bufen-xianxiang xue yu renshilun yanjiu, Shibao wenhua chuban qiye gongsi, Taibei. (in Chinese).

Husaier. (1999), Jingyan yu panduan, Sanlian shudian, Beijing. (in Chinese).

Husaier. (2000), Neizai shijian yishi xianxiang xue, Huaxia chuban she, Beijing. (in Chinese).

Husaier. (2001), Ouzhou kexue de weiji yu chaoyue lun de xianxiang xue, Shangwu yin shuguan, Beijing. (in Chinese).

Husaier. (2002), Shenghuo shijie xianxiang xue, Shanghai yiwen chuban she, Shanghai. (in Chinese).

Husaier. (2002), Lunli xue yu jiazhi lun de jiben wenti, Zhongguo chengshi chuban she, Beijing. (in Chinese).

Husaier. (2002), Di ka'er shi de chensi, Zhongguo chengshi chuban she, Beijing. (in Chinese).

Jansena J., Cai Wenjing. (2018), "Husserlian Phenomenology: Current Chinese Perspectives", Comparative and Continental Philosophy, Vol. 10, No 1, pp. 2-6. 
Jin Xiping. (1995), Haidegeer zaoqi sixiang yanjiu, Shanghai renmin chuban she, Shanghai. (in Chinese).

Jin Xiping. (2007), "Youding Shen: The First Phenomenologist in China", in Lau Kwok-Ying, Drummond J. J. (Eds.), Husserl's Logical Investigations in the New Century: Western and Chinese Perspectives, Springer, Dordrecht, pp. 21-32.

Ke Xiaogang. (2004), Haidegeer yu Heigeer shijian sixiang bijiao yanjiu, Tongji daxue chubanshe, Shanghai. (in Chinese).

Kelinsi•Jiefu. (2005), Haidegeer yu Nacui, Beijing daxue chuban she, Beijing. (in Chinese).

Kelaimang•Katelin. (2002), Mading yu Hanna: Haidegeer he ta de qizi ji qingren, Dongfang chuban she, Beijing. (in Chinese).

Kern I. (2007), "China”, in Lester Embree et al. (Eds.), Encyclopedia of Phenomenology. Springer, Dordrecht, pp. 99-101.

Kiktenko V. O. (2018), "Ohlyad istoriyi analitychnoyi filosofiyi v Kytayi (XX pochatok XXI stolittya)", Skhidnyy svit, No 2, ss. 17-29. (in Ukrainian).

Kuerpozhe•Dawei. (2004), Chuncui xiandai xing pipan: Heigeer, Haidegeer ji qi yihou, Shangwu yin shuguan, Beijing. (in Chinese).

Lau Kwok-Ying, Drummond J. J. (Eds.). (2007), Husserl's Logical Investigations in the New Century: Western and Chinese Perspectives, Springer, Dordrecht.

Lau Kwok-Ying, Cheung Chan-Fai, Kwan Tze-Wan. (2010), Identity and Alterity: Phenomenology and Cultural Traditions, Königshausen \& Neumann, Würtzburg.

Lau Kwok-ying, Yu Chung-chi. (2012), Phenomenology and Human Experience, Traugott, 2012.

Lau Kwok-ying, Yu Chung-Chi (2014), Border-crossing: phenomenology, interculturality and interdisciplinarity, Königshausen \& Neumann, Würzburg.

Lee Chun Lo. (2018), "Time, the Image of Absolute Logos: A Comparative Analysis of the Ideas of Augustine and Husserl", Comparative and Continental Philosophy, Vol. 10, No 1, pp. 50-61.

Leung Ka-wing. (2018), "Husserl's Notion of Sensation and Merleau-Ponty's Critique", Comparative and Continental Philosophy, Vol. 10, No 1, pp. 35-49.

Li Guiliang. (1963), Husaier xianxiang xue, Shifan daxue bian yin, Taibei. (in Chinese).

Li Wentang. (2002), Zhenli zhi guang: Feixite yu Haidegeer lun SEIN, Jiangsu renmin chubanshe, Nanjing. (in Chinese).

Li Zhi. (2003), Lun Haidegeer de xiandai xing pipan: Ling yi zhong hou xiandai zhuyi, Shoudu shifan daxue chubanshe, Beijing. (in Chinese).

Li Zhongwei. (2013), Hui dao xianxiang xue de yixiang xing lilun, Zhongguo zhengfa daxue chubanshe, Beijing.

Li Zhongwei. (2018), "From the Naturalistic to the Transcendental Conception of Intentionality", Comparative and Continental Philosophy, Vol. 10, No 1, pp. 74-87.

Liu Fangtong. (1981), Xiandai xifang zhexue, Renmin chuban she, Beijing. (in Chinese).

Liu Jinglu. (2001), Haidegeer renxue sixiang yanjiu, Zhongguo renmin daxue chubanshe, Beijing. (in Chinese).

Liu Xiaoli. (2010), “Gödel's philosophical program and Husserl's phenomenology", Synthese, Vol. 175, No 1, pp. 33-45.

Liu Xuguang. (2004), Haidegeer yu meixue, Shanghai sanlian shudian, Shanghai. (in Chinese). 
Liu Yongfu. (2000), Husaier xianxiang xue, Haidegeer ben shi xue yin luncong suo zhi xue de jiaodu chongxin jiedu Husaier yu Haidegeer, Xibei daxue chubanshe, Xi'an. (in Chinese).

Luo Keting. (1980), "Husaier xianxiang xue shi dui xiandai ziran kexue fazhan de fandong", Zhexue yanjiu, No 3, pp. 69-77. (in Chinese).

Luosen. (2004), Shi yu zhexue zhi zheng: Cong bolatu dao Nicai, Haidegeer. Huaxia chuban she, Beijing. (in Chinese).

Lutekaiweiqizhe. (1989), Cong fu luo yi de dao haide ge er cunzai jingshen fenxi pingshu, Dongfang chuban she, Beijing. (in Chinese).

Ma'erhuoer. (2007), Haidegeer yu "Cunzai yu shijian", Guangxi shifan daxue chuban she, Guilin. (in Chinese).

Meiyizhe•Laiyinhade. (2003), Haidegeer yu dongya sixiang, Zhongguo shehui kexue chuban she, Beijing. (in Chinese).

Molisi•Make•Fuluomang. (2005), Haidegeer shi xue, Shanghai yiwen chuban she, Shanghai. (in Chinese).

Ni Liangkang, Iso Kern (1997), "Phänomenologische Forschungen in China", Phänomenologische Forschungen Neue Folge, Vol. 2, No 2, pp. 308-312.

Ni Liangkang. (2016), Husaier yu Haidegeer, Shangwu yin shuguan, Beijing. (in Chinese).

Parkes G. (1987), Heidegger and Asian Thought, University of Hawaii, Honolulu.

Peng Fuchun. (2000), Wu zhi wu hua - lun Haidegeer sixiang daolu de hexin wenti, Shanghai sanlian shudian, Shanghai.

Safulansiji•Lü. (1998), Haidegeer chuan-laizi deguo de dashi, Shangwu yin shuguan, Beijing. (in Chinese).

Sate. (1987), Cunzai уи хижи, Sanlian shudian, Beijing. (in Chinese).

Sate. (1988), Cunzai zhuyi shi yi zhong rendao zhuyi, Shanghai yiwen chuban she, Shanghai. (in Chinese).

Sate. (1989), Ciyu, Shanghai yiwen chuban she, Shanghai. (in Chinese).

Shelei. (1994), Ai de zhixu, Sanlian shudian gongsi, Xianggang. (in Chinese).

Shen Youding. (1992), Shen Youding wenji, Renmin chuban she, Beijing. (in Chinese).

Shi•yuyan •si (1990), Wenhua yishu chuban she, Beijing. (in Chinese).

Sitanna•Qiaozhi. (1988), Cunzai zhuyi zu shiye: Haidegeer, Hunan renmin chubanshe, Zhangsha.

Sitanna•Qiaozhi. (1989), Haidegeer, Zhongguo shehui kexue chubanshe, Beijing.

Song Zuliang. (1993), Zhengjiu diqiu he renlei weilai - Haidegeer de houqi sixiang, Zhongguo shehui kexue chuban she, Beijing. (in Chinese).

Sun Zhouxing. (1994), Shuo bu ke shuo zhi shenmi: Haidegeer houqi sixiang yanjiu, Sanlian shudian Shanghai fendian, Shanghai. (in Chinese).

Teng Shouyao. (1996), Haidege, Shengzhi chubanshe, Taibei. (in Chinese).

Tu Chenglin. (1994), Xianxiang xue de shiming: Cong Husaier, Haidegeer dao Sate, Guangdong renmin chuban she, Guangzhou. (in Chinese).

Wang Heng. (2006), Shijian xing, zishen yu ta zhe: Cong Husaier, Haidegeer dao Lieweinasi. Jiangsu renmin chuban she, Nanjing. (in Chinese).

Wang Jinlin. (2002), Shijie lishi yiyi de benzhi dao shuo - cong Haidegeer de jiedu kan makesi zhexue di dang dai xing, Shanghai jiaoyu chubanshe, Shanghai. (in Chinese). 
Wang Qingjie. (2004), Jieshixue, Haidegeer yu ru dao jin shi, Zhongguo renmin daxue chubanshe, Beijing. (in Chinese).

Wang Qingjie. (2015), Haidegeer yu zhexue de kaiduan, Shenghuo dushu xinzhi sanlian shudian, Beijing. (in Chinese).

Wang Qingjie. (2017), Haidegeer, Shenghuo dushu xinzhi sanlian shudian, Beijing. (in Chinese).

Wang Wensheng. (1997), Husaier yu Haidege, Yuan liu, Taipei. (in Chinese).

Wolin-Lichade. (2000), Cunzai de zhengzhi: Haidegeer de zhengzhi sixiang, Shangwu yin shuguan, Beijing. (in Chinese).

Wolin•Lichade. (2005), Degeer de dizi: Alunte, Leiweite, Yuenasi he Ma'erkusai, Jiangsu jiaoyu chuban she, Nanjing. (in Chinese).

Wu kunru. (1981), Xianxiang xue lunwen ji, Liming, Taibei.

Wu Zengding. (2018), "The Problem of Origin in Husserl's Phenomenology", Comparative and Continental Philosophy, Vol. 10, No 1, pp. 21-34.

Xia Hanping. (2001), Haidegeer chuan, Changjiang wenyi chubanshe, Wuhan. (in Chinese).

Xiang Tuijie. (1989), Haidege, Dongda tushu gufen youxian gongsi, Taibei. (in Chinese).

Xiong Wei, bian. (1994), Xianxiang xue yu Haidege, Yuanliu chuban shiye gufen youxian gongsi, Taibei. (in Chinese).

Xingshi xianshi de xianxiang xue-haide ge er zaoqi fu lai bao wenxuan (2004), Shanghai tongji daxue chuban she, Shanghai. (in Chinese).

Yang Rengeng. (1929), "Xianxiang xue gailun", Min duo, Vol. 10, No 1 (page numbers unknown). (in Chinese).

Yangzhe•Zhuli'an. (2002), Haidegeer zhexue nacui zhuyi, Liaoning jiaoyu chuban she, Shenyang. (in Chinese).

Yanjiang yu lunwen ji. (2005), Sanlian shudian, Beijing. (in Chinese).

Ye Xiushan. (1988), Si •shi •shi-xianxiang xue he cunzai zhexue yanjiu, Renmin chubanshe, Beijing. (in Chinese).

Yu Chung-chi, Lau Kwok-ying. (2012), Phenomenology and Human Experience, Bautz, Traugott.

Yu Hong. (1991), Si yu shi de duihua: Haidegeer shi xue yin lun, Zhongguo shehui kexue chuban she, Beijing. (in Chinese).

Yu Hong. (2005), Yishu yu guijia: Nicai•Haidegeer•Fuke, Zhongguo renmin daxue chubanshe, Beijing. (in Chinese).

Yu Xuanmeng. (1989), Xiandai xifang de chaoyue sikao: Haidegeer de zhexue, Shanghai renmin chuban she, Shanghai. (in Chinese).

Yuehanxun•Patelixia•Aotanbode. (2002), Haidegeer, Zhonghua shuju, Beijing. (in Chinese).

Yuesefu•Kekeermansi. (1996), Haidegeer de <Cunzai yu shijian $>$ dui zuowei jiben cunzai lun de ci zai de fenxi, Chenxiaowen deng yi, Shangwu yin shuguan, Beijing. (in Chinese).

Zhang Canhui. (1996), Haidegeer yu Husaier xianxiang xue, Dongda tushu gufen youxian gongsi, Taibei. (in Chinese).

Zhang Qingxiong. (1995), Xiong Shili de xin wei shi lun yu Husaier de xianxiang xue, Shanghai renmin chuban she, Shanghai. (in Chinese).

Zhang Rulun. (1995), Haidegeer yu xiandai zhexue, Fudan daxue chuban she, Shanghai. (in Chinese).

Zhang Wenxi. (2004), Dianfu xing'ershangxue: Makesi he Haidegeer zhi lun, Zhongguo shehui kexue chubanshe, Beijing. (in Chinese). 
Zhang Xiangen. (2004), Cunzai•zhenli•yuyan: Haidegeer meixue sixiang yanjiu, Wuhan daxue chuban she, Wuhan. (in Chinese).

Zhang Xianglong. (1996), Haidegeer sixiang yu zhongguo tiandao-zhongji shi yu de kaiqi yu jiaorong, Sanlian shudian, Beijing. (in Chinese).

Zhang Xianglong. (1998), Haidegeer chuan, Hebei renmin chubanshe, Shijiazhuang. (in Chinese).

Zhang Xianglong. (2001), Cong xianxiang xue dao Kongfuzi, Shangwu yin shuguan, Beijing. (in Chinese).

Zhang Xianglong. (2011), Xianxiang xue sichao zai zhongguo, Shoudu shifan daxue chuban she, Beijing. (in Chinese).

Zhao Weiguo. (2006), Haidegeer de shijian yu shiøian xing wenti yanjiu, Zhongguo shehui kexue chuban she, Beijing. (in Chinese).

Zheng Pirui. (2018), "What Awakens the Alien experience: starting from the incorporation of the lived body", Comparative and Continental Philosophy, Vol. 10, No 1, pp. 62-73.

Zhong Hua. (2004), Cong xiaoyao you dao lin zhonglu: Haidegeer yu Zhuangzi shi xue sixiang bijiao, Hualing chubanshe, Beijing. (in Chinese).

Zhou Minfeng. (2002), Zouxiang da zhihui: Yu Haidegeer duihua, Sichuan renmin chubanshe, Chengdu. (in Chinese).

\section{ІСТОРИЧНІ ЕТАПИ РОЗВИТКУ ФЕНОМЕНОЛОГІЇ В КИТАЇ}

\section{B. О. Кіктенко}

У статті розглядається історія розвитку феноменологічного руху в Китаї з 1920-х років й до сьогодення. Відзначено, що ідеї феноменології поступово проникли в Китай протягом 1920-1960-х років, проте до кінця 1970-х років переклади і дослідження класиків західної феноменології в Китаї були нечисленними і безсистемними. 3 кінця 1970-х й до середини 1980-х років відбулося повноцінне поширення феноменології в Китаї. Далі з кінця 1980-х й до середині 1990-х років був розпочатий переклад китайською мовою фундаментальних феноменологічних праць Е. Гуссерля, М. Гайдеггера, Ж.-П. Сартра, М. Шелера. Згодом, із середини 1990-х років й по теперішній час, ця перекладацька робота вийшла на системний рівень, що позитивно вплинуло на розвиток феноменології в Китаї. На сьогодні феноменологія в Китаї перебуває в основному на стадії сприйняття цього напрямку західної думки і формування власних феноменологічних досліджень, у яких виділяють три течії 1) актуальність феноменології для конфуціанства і буддизму, 2) феноменологія в історичному контексті, 3) діалог між феноменологією та аналітичною філософією. Все це демонструє успішну інтеграцію до світової науки китайських філософів, які до того ж формують власний погляд на розуміння структури свідомості людини.

Ключові слова: феноменологія, свідомість, буття, час, інтенціональність, конфуціанство, даосизм, буддизм, Китай та Захід

\section{ИСТОРИЧЕСКИЕ ЭТАПЫ РАЗВИТИЯ ФЕНОМЕНОЛОГИИ В КИТАЕ}

\section{B. А. Киктенко}

В статье рассматривается история развития феноменологического движения в Китае с 1920-х годов и до наших дней. Отмечено, что идеи феноменологии постепенно проникли в Китай в течение 1920-1960-х годов, однако к концу 1970-х годов переводы и исследования классиков западной феноменологии в Китае были немногочисленными и бессистемными. С конца 1970-х и до середины 1980-х годов произошло полноценное распространение феноменологии в Китае. Затем с конца 1980-х и до середины 1990-х годов был начат перевод на китайский язык фундаментальных феноменологических работ Э. Гуссерля, М. Хайдеггера, Ж.-П. Сартра, М. Шелера. 
В дальнейшем, с середины 1990-х годов и по настоящее время, эта переводческая работа вышла на системный уровень, что положительно повлияло на развитие феноменологии в Китае. В настоящее время феноменология в Китае находится в основном на стадии восприятия этого направления западной мысли и формирования собственных феноменологических исследований, в которых выделяют три течения: 1) актуальность феноменологии для конфуцианства и буддизма, 2) феноменология в историческом контексте, 3) диалог между феноменологией и аналитической философией. Все это демонстрирует успешную интеграцию в мировую науку китайских философов, которые к тому же формируют собственный взгляд на понимание структуры сознания человека.

Ключевые слова: феноменология, сознание, бытие, время, интенциональность, конфуцианство, даосизм, буддизм, Китай и Запад

Стаття надійшла до редакиії 13.09.2018 